\title{
Information model of the structure of the heat and power system of pulp and paper production and a systematic approach to its improvement
}

\author{
$L V$ Plotnikova*, I I Chilikova, $E V$ Khramova and $V V$ Plotnikov \\ Kazan State Power Engineering University, 51 Krasnoselskaya Street, Kazan, Russia
}

\begin{abstract}
The stages of the system analysis of an industrial energy system with a complex structure are considered by the example of pulp and paper production. The software of the structural and thermodynamic stages of the analysis is presented. The results of thermodynamic calculations of the elements of the energy system by the optimal sequence are given. A variant of the system modernization using a heat pump is presented.
\end{abstract}

\section{Introduction}

Pulp production is one of the largest industrial consumers of thermal energy. Pulp and paper production is a complex structure with many elements that interact with each other and with the environment. The interaction of elements is often of a reverse nature, which leads to recycling and numerous iterations in the calculations of the system and in the selection of measures for the modernization of production [1 - 3].

To reduce the number of iterations in the calculation of the scheme, it is proposed to use the method of structural modeling and the development of an information model of production based on it. This approach simplifies the structure of multi-element production schemes and can be the basis for conducting thermodynamic calculations of the system. The structural modeling method formed the basis of the developed software [4 - 7], which can be used when conducting a system analysis of production and making decisions on the return of waste energy flows to the technological circuit.

\section{Stage of structural analysis}

The object is the heat technology scheme of pulp and paper production at JSC "Polygraphboard", Balakhna (Russia), including 110 elements, 193 streams [7]. All elements and threads are represented as an oriented graph. The scheme is decomposed by weak links (flows that are not included in the closed contours of the scheme) into separate blocks. Let us dwell on one of the blocks selected as a result of decomposition (fragment Figure 1). This unit is also the most energy-intensive sector of pulp and paper production. The stages of the program are considered (Figure 2, Figure 3). The scheme is represented as a matrix (Figure 2 (a)); the number in the matrix is the stream number. The matrix is multiplied according to the rules of Boolean algebra (Figure 2 (a)). At certain stages of the matrix multiplication, there are closed sequences - cycles (Figure 2 (b)). Next is the minimum number of streams, the conditional discontinuity of which will allow to carry out a sequential thermodynamic calculation of the circuit with a minimum of iterations (Figure 2 (c, d)), (Figure 2 (e, f)).

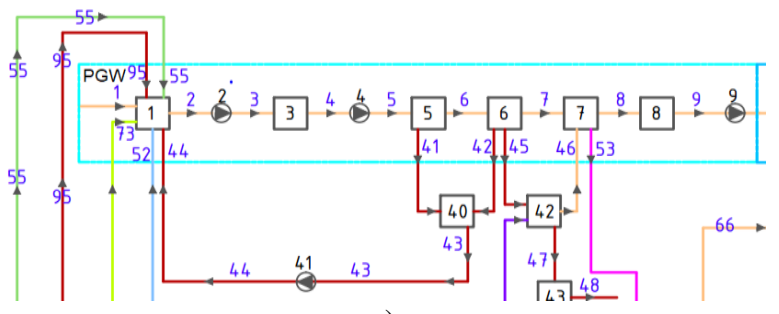

a)

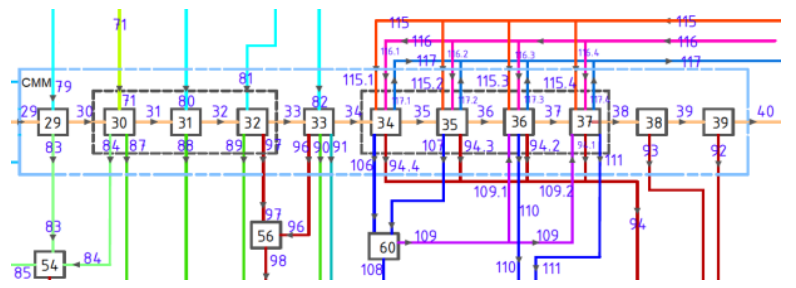

b)

Fig. 1. Fragments of the section $(a, b)$ of the information scheme of the block of the cardboard machine: PGW - pregrinding workshop; CMM - cardboard making machine; numbers in squares - numbers of positions of system elements; the numbers on the arrows are the position numbers of the system streams. 


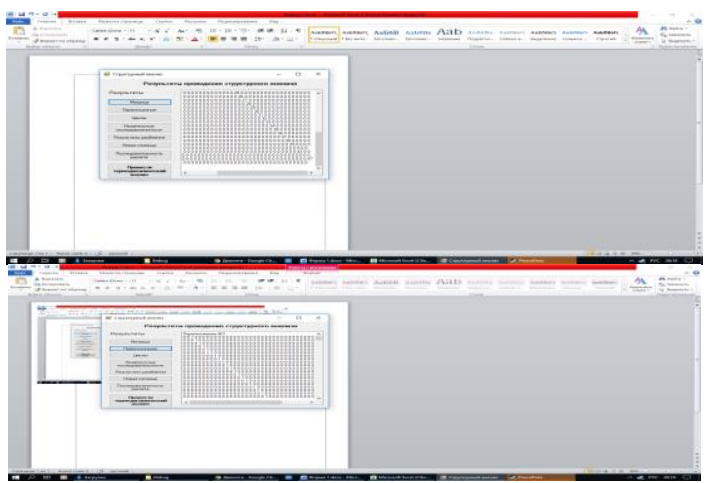

(a)

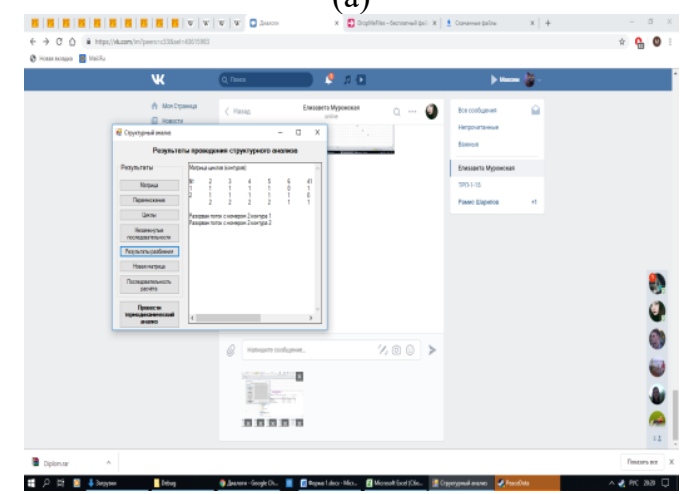

(c)

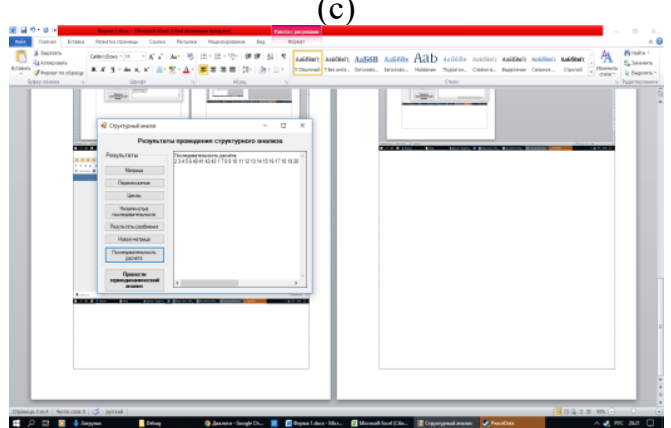

(e)

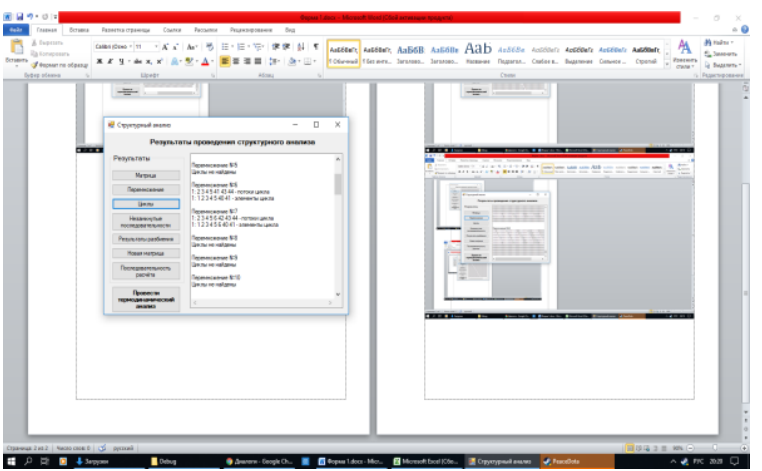

(b)

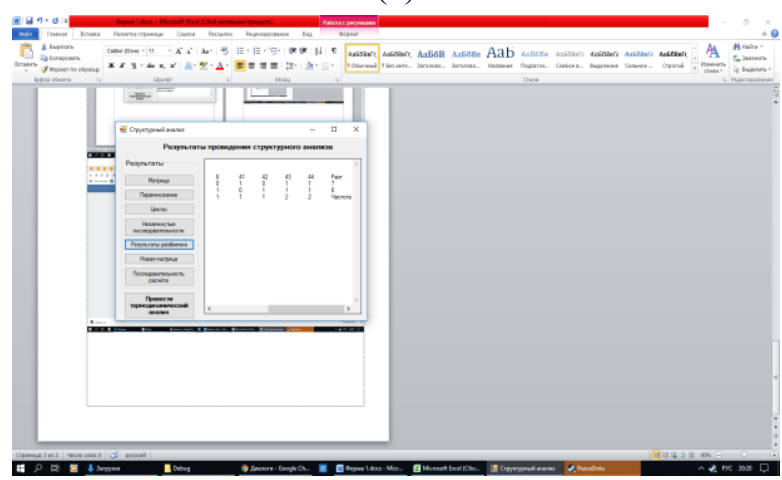

d)

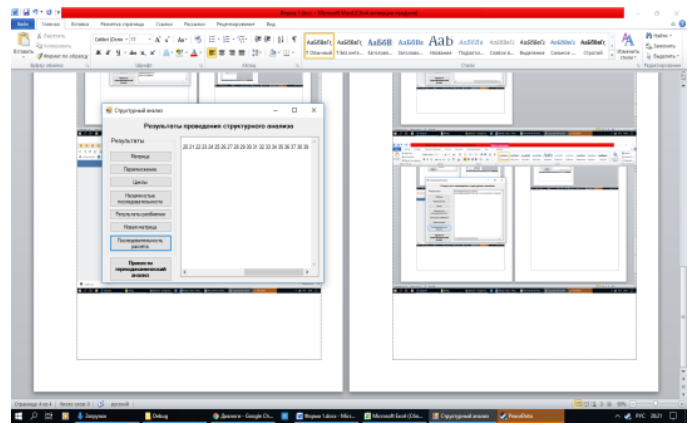

(f)

Fig. 2. Stages of the program for the structural analysis of complex schemes (a, b, c, d).

\section{Stage thermodynamic analysis}

The software provides for the possibility of carrying out thermodynamic calculations based on the found sequence and determining the efficiency of the apparatus (Figure 4). Let us enter the flow parameters when entering the scheme matrix at the structural analysis stage and entering formulas for the scheme elements (Figure 4 (a)). Also provides for the calculation of performance indicators of the elements of the system (Figure 4 (b)); explanation of symbols in the Figure 3 (b).

The obtained parameters of the flows of the block of the cardboard machine in the form of the initial data and the results of the thermodynamic calculation are presented in table 1 . The values of thermal and exergic power are determined by temperature, flow rate, pressure for each flow. The greatest exergetic power among the outlets is at the condensate stream 113 and at the air stream 117.
Further, the possibility of returning the energy of these flows to this scheme is considered. For this purpose, a thermal and exergy calculation of the elements included in the block is carried out [8 - 11]. The results of the exergic calculation are shown in table 2.

From table 2 it is seen that for those devices in which there is no heat and mass transfer, the efficiency is high, therefore, there is no need to make their modernization. And at devices 33 - 37, the efficiency is much lower. Therefore, it is necessary to carry out the modernization of these devices, namely, to realize the return of the energy of the streams of the greatest exergy potential to these devices $[12,13]$.

\section{Conclusions}

Condensate flow 13 was previously used in the scheme under consideration in the system for collecting and returning condensate, therefore it is not considered in the 


\begin{tabular}{|c|c|}
\hline 撮 Структурный анализ & structural analysis \\
\hline Результтаты проведения структурного өнализа & results of structural analysis \\
\hline Marpers & matrix \\
\hline Mepenososerve & multiplication \\
\hline Lnow & cycles \\
\hline 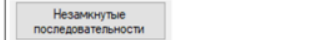 & open sequences \\
\hline 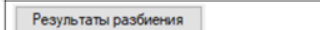 & split results \\
\hline Hoosan matrous & new matrix \\
\hline 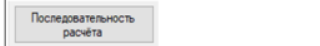 & calculation sequence \\
\hline 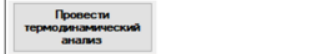 & apply thermodynamic analysis \\
\hline Lиклы не найенты & cycles not found \\
\hline потоки Lикла & streams of cycle \\
\hline элементы цикла & elements of cycle \\
\hline Матрица циклов (контуров): & matrix of cycles \\
\hline Разорван поток с номером 2 контрра 1 & stream number 2 of circuit 1 is broken \\
\hline Parr & rank \\
\hline
\end{tabular}

a)

\begin{tabular}{|c|c|}
\hline 国 Ввод искодных данных & \\
\hline Ввод матрицы & matrix input \\
\hline Ввод инФормации о потоках & input streams information \\
\hline Ввод информашии об установках & input elements information \\
\hline $\begin{array}{l}\text { Провести } \\
\text { структррый анализ }\end{array}$ & apply structural analysis \\
\hline 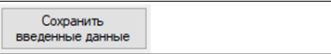 & save entered data \\
\hline Потоки иустановси & streams and elements \\
\hline 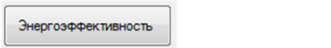 & energy efficiency \\
\hline $\begin{array}{l}\text { Pезультаты проведения структурного n } \\
\text { гертодинамического әнализа }\end{array}$ & results of structural and thermodynamic analysis \\
\hline Фopmyna & formula \\
\hline $\begin{array}{l}\text { Номер } \\
\text { yстановки }\end{array}$ & installation number \\
\hline Система & system \\
\hline
\end{tabular}

b)

Fig. 3. Notation software: (a) - structural analysis; (b) - thermodynamic analysis.

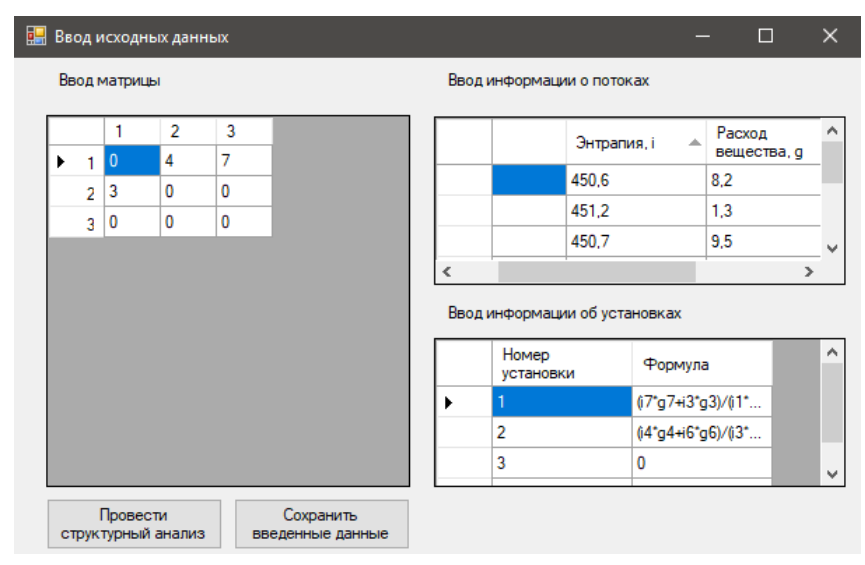

a)

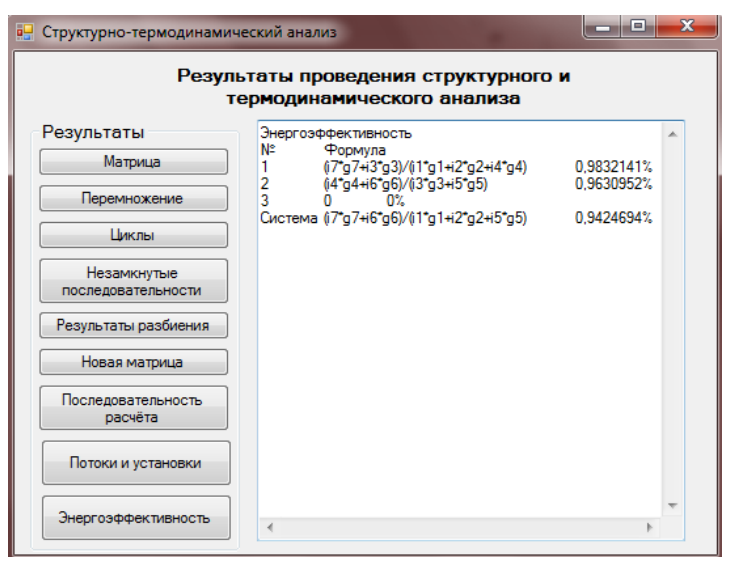

b)

Fig. 4. The work of the program during the thermodynamic analysis $(a, b)$.

proposed return system. The circuit for returning the airflow $117[14,15]$ is shown in Figure 5.

It has been proposed to use a heat pump in the drying part of a cardboard machine for utilizing the heat flow of spent moist air 17 in order to bring the parameters of the spent moist air to the required parameters of heating dry air. Cold air enters the condenser of the heat pump 2, where it is heated to the required technology temperature of $110{ }^{\circ} \mathrm{C}$ and sent to the drying chamber 5 . The air temperature in the drying chamber decreases and the

Table 1. The flow parameters of the board machine.

\begin{tabular}{|l|c|c|c|c|c|c|c|c|}
\hline Stream name & $\begin{array}{c}\text { № } \\
\text { stream }\end{array}$ & $\begin{array}{c}\text { From the } \\
\text { apparatus }\end{array}$ & $\begin{array}{c}\text { Into the } \\
\text { apparatus }\end{array}$ & $\begin{array}{c}\text { Pressure } \mathrm{P}, \\
\mathrm{MPa}\end{array}$ & $\begin{array}{c}\text { Temperature } \\
\mathrm{T},{ }^{\circ} \mathrm{C}\end{array}$ & $\begin{array}{c}\text { Outgo G, } \\
\mathrm{kg} / \mathrm{s}\end{array}$ & $\begin{array}{c}\text { Thermal } \\
\text { power Q, } \mathrm{kW}\end{array}$ & $\begin{array}{c}\text { Exergy } \\
\text { power ET, } \\
\mathrm{kW}\end{array}$ \\
\hline Warm air & 116 & - & $34,35,36,37$ & 0.3 & 110 & 31.17 & 3440.13 & 987.64 \\
\hline Condensate & 106 & 34 & 60 & 0.332 & 137.0 & 0.79 & 454.92 & 151.95 \\
\hline Condensate & 107 & 35 & 60 & 0.332 & 137.0 & 0.79 & 454.92 & 151.95 \\
\hline Condensate & 110 & 36 & 61 & 0.332 & 137.0 & 0.79 & 454.92 & 151.95 \\
\hline Condensate & 111 & 37 & 61 & 0.332 & 137.0 & 0.79 & 454.92 & 151.95 \\
\hline Boiling pairs & 109 & 60 & 36,37 & 0.329 & 137.0 & 0.2 & 545.96 & 182.36 \\
\hline Condensate & 108 & 60 & 62 & 0.332 & 137.0 & 1.39 & 795.03 & 265.56 \\
\hline Condensate & 112 & 61 & 62 & 0.332 & 137.0 & 1.59 & 909.84 & 303.91 \\
\hline Condensate & 113 & 62 & 63 & 0.332 & 137.0 & 2.97 & 1704.87 & 569.47 \\
\hline Steam & 115 & 64 & $34,35,36,37$ & 0.345 & 138.4 & 3.17 & 8652.82 & 2909.85 \\
\hline Exhaust air & 117 & $34,35,36,37$ & - & 0.3 & 74.0 & 31.17 & 2942.44 & 627.22 \\
\hline
\end{tabular}


Table 2. The results of exergic calculation of elements included in the block.

\begin{tabular}{|c|c|c|c|c|}
\hline \begin{tabular}{|c|}
$\begin{array}{c}\text { No. of flow at the entrance to } \\
\text { the element - No. of flow at the } \\
\text { exit from the unit }\end{array}$ \\
\end{tabular} & Exergic power flow, $\mathrm{kW}$ & $\begin{array}{c}\text { Change of exergy power in } \\
\text { the element, } \mathrm{kW}\end{array}$ & $\begin{array}{l}\text { Losses of exergy } \\
\text { power in the } \\
\text { element, } \mathrm{kW}\end{array}$ & $\begin{array}{c}\text { Exergetic } \\
\text { efficiency, \% }\end{array}$ \\
\hline \multicolumn{5}{|c|}{ Headbox CMM 29} \\
\hline 29,79 (input) & 6132.71 & 149.51 & 149.51 & 97.56 \\
\hline 30,83 (output) & 5983.20 & & & \\
\hline \multicolumn{5}{|c|}{ Pre-dehydration site 30} \\
\hline 30,71 (input) & 5073.28 & 217.96 & 217.95 & 95.70 \\
\hline $31,84,87$ (output) & 4855.32 & & & \\
\hline \multicolumn{5}{|c|}{ Removal of water in the suction box 31} \\
\hline 31,80 (input) & 654.06 & 2.77 & 2.77 & - \\
\hline 32,88 (output) & 651.28 & & & \\
\hline \multicolumn{5}{|c|}{ Water removal in gauch-shaft 32} \\
\hline 32,81 (input) & 438.29 & 54.57 & 54.57 & 87.54 \\
\hline $33,89,97$ (output) & 383.72 & & & \\
\hline \multicolumn{5}{|c|}{ Dehydration and compaction in the press section of the CMM 33} \\
\hline 33,82 (input) & 556.00 & 229.96 & 229.96 & 58.64 \\
\hline $34,90,91,96$ (output) & 326.04 & & & \\
\hline \multicolumn{5}{|c|}{ Drying in the 1st cylinder group of the drying part 34} \\
\hline $115.1,116.1-106,117$ & $2106.06-813.39$ & 1292.67 & 492.53 & 61.89 \\
\hline $34-35,94.4$ & $105.21-905.39$ & 800.14 & & \\
\hline \multicolumn{5}{|c|}{ Drying in the 2nd cylinder group of the drying part 35} \\
\hline $115.2,116.2-107,117.2$ & $2106.06-813.39$ & 1292.67 & 396.15 & 69.35 \\
\hline $35-36,94.3$ & $216.18-1112.67$ & 896.52 & & \\
\hline \multicolumn{5}{|c|}{ Drying in the 3rd group of cylinders of the drying part 36} \\
\hline $115.3,116.3,109.1-110,117.3$ & $2282.50-1123.81$ & 1158.69 & 469.47 & 59.48 \\
\hline $36-37,94.2$ & $423.45-1112.67$ & 689.21 & & \\
\hline \multicolumn{5}{|c|}{ Drying in the 4th group of cylinders of the drying part 37} \\
\hline $\begin{array}{c}115.4,116.4,109.2-111 \\
117.4\end{array}$ & $2282.5-1675.12$ & 607.38 & 322.56 & 46.89 \\
\hline $37-38,94.1$ & $423.45-708.27$ & 284.81 & & \\
\hline \multicolumn{5}{|c|}{ Surface Enhancement in Machine Calender and Peripheral Winding 38} \\
\hline 38 (input) & 19.05 & \begin{tabular}{|r|r}
0.13 \\
\end{tabular} & 0.13 & - \\
\hline 39,93 (output) & 18.92 & & & \\
\hline \multicolumn{5}{|c|}{ Longitudinal cutting machine 39} \\
\hline 39 (input) & 18.66 & 7.06 & 7.06 & - \\
\hline 40,92 (output) & 11.59 & & & \\
\hline
\end{tabular}

moisture content rises due to heat and mass transfer. Moisture is removed from the product and this moisture is transferred to the air stream. Next, moist air with a temperature of $74{ }^{\circ} \mathrm{C}$ is sent to the evaporator of the heat pump 4, where it is cooled. Simultaneously with the cooling process, the precipitated moisture is removed. In the evaporator 4, the exhaust moist air acts as a source of thermal energy, the potential of which rises in the heat pump.

The results of the calculations showed that the heat of the outgoing air is sufficient to heat the air entering the drying unit.

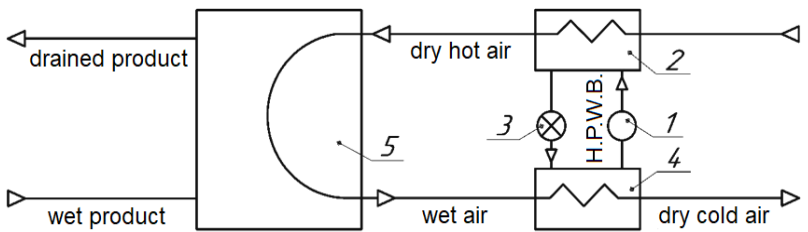

Fig. 5. Scheme of the return heat of the flow of exhaust air in the drying part of the cardboard machine: 1 - compressor; 2 capacitor; 3 - throttle valve; 4 - evaporator; 5 - drying chamber; H.P.W.B. - heat pump working body. 
Using the scheme with a heat pump, $6245.89 \mathrm{~kW}$ of additional thermal energy was obtained through the use of $2942.44 \mathrm{~kW}$ of wet flue gas energy. In the case of using a drying installation with a conventional air heater, an additional $3789.24 \mathrm{~kW}$ of energy would be consumed in the electric heater.

As a result of the use of the heat pump during the drying process, the exergic coefficient of system utilization [12] of the block under consideration increased from $49.5 \%$ to $65.6 \%$.

\section{References}

1. E.I. Akulinin, O.O. Golubyatnikov, S.I. Dvoretsky, D. Dvoretsky, Software and hardware appliance for research, modelling and optimisation of cyclic processes of gas mixture separation, Int. Multidisciplinary Scientific Geo Conf. Geology and Mining Ecology Management, 18(4.2), 599-606 (2018)

2. G.M. Ostrovsky, N.N. Ziyatdinov, T.V. Lapteva, Optimal design of process systems under uncertainty Computing and Systems Technology Division Core Programming, Area at the 2015 AIChE Annual Meeting, 1, 295-296 (2015)

3. N.N. Ziyatdinov, I.I. Emel'yanov, L.Q. Tuen, Method for the Synthesis of Optimum Multistage Heat Exchange Network, Theor. Found. of Chem. Eng. 52(6), 943-955 (2018)

4. L.V. Plotnikova, L.A. Kashipova, R.A. Ishmuratov, Modeling of heat and power system optimal structure using software, J. of Eng. and App. Sci. 11(14), 3028-34 (2016)

5. L.V. Plotnikova, L.A. Kashipova, Development of software for analysis of the structure of industrial heat and power systems, 2nd Int. Conf. on Industrial Engineering, Applications and Manufacturing, 2, 7911675 (2016)

6. L.V. Plotnikova, L.A. Kashipova, R.A. Ishmuratov, A.A. Zvegintsev, N.K. Nureyev, Program implementation of the system analysis of the chemical and technological scheme complex structures of petrochemical productionn Mess. of the Kaz. Tech. uni. 18(8), 198-202

7. L.V. Plotnikova, I.I. Chilikova, V.A. Dodonov, Structural analysis of the heat technological complex for the production of paper OAO Polygraphkarton, Eng. J. of Don, 4(43), 29 (2016)

8. J. Wang, S. Li, G. Zhang, Y. Yang, Performance investigation of a solar-assisted hybrid combined cooling, heating and power system based on energy, exergy, exergo-economic and exergoenvironmental analyses, En. Conv. and Manag., 196, 227-241 (2016)

9. X. Zhang, R. Zeng, T. Du, X. Liu, H. Li, Conventional and energy level based exergoeconomic analysis of biomass and natural gas fired polygeneration system integrated with ground source heat pump and PEM electrolyzer, En. Conv. and Manag., 195, 313-327 (2019)
10. B.S. Sazhin, A.P. Bulekov, V.B. Sazhin, Performance evaluation of apparatuses operating in active hydrodynamic modes by exergy analysis, Theor. Found. of Chem. Eng., 33(5), 471-476 (1999)

11. A. Schlueter, F. Thesseling, Building information model based energy/exergy performance assessment in early design stages, Automat. in Constr., 18(2), 153-163 (2009)

12. L.V. Plotnikova, I.I. Chilikova, S.Y. Sitnikov, G.I. Efremov, Systematic approach to the assessment of energy complex efficiency for thermal energy production with heat power saving transformer turning on Int., J. of Pharm. and Tech., 8 (4), 26727-37 (2016)

13. L.V. Plotnikova, I.I. Chilikova, E.E. Kostyleva, S.Y. Sitnikov, The use of heat pump installations as part of waste energy convertion complexes in the joint generation of electrical and thermal energy, IOP Conf. Series: Earth and Environmental Science, Int. Scientific Conf. "Efficient waste treatment - 2018", 012067 (2019)

14. P. Gataric, B. Sirok, M. Hocevar, L. Novak, Modeling of heat pump tumble dryer energy consumption and drying time Dry, Tech., 37(11), 1396-1404 (2019)

15. W.F. He, T. Wen,D. Han, R.Y. Li, W.C. Zhong, Energetic, entropic and economic analysis of a heat pump coupled humidification dehumidification desalination system using a packed bed dehumidifier, Energy Conversion and Management, 194, 11-21 (2015) 